\title{
Increased Diagnostic Probability of Subclinical Cushing's Syndrome in a Population Sample of Overweight Adult Patients with Type 2 Diabetes Mellitus
}

\section{artigo original}

\author{
Maria Silvia S. Caetano \\ REgINA DO CARMO SIIVA \\ Claudio E. Kater
}

Division of Endocrinology, Department of Medicine,

Federal University of São Paulo, UNIFESP/EPM, São Paulo, SP.
Recebido em 19/01/07

Aceito em 06/06/07

\section{ABSTRACT}

Endogenous Cushing's Syndrome (CS) is unusual. Patients with subclinical CS (SCS) present altered cortisol dynamics without obvious manifestations. CS occurs in $2-3 \%$ of obese poorly controlled diabetics. We studied 103 overweight adult outpatients with type 2 diabetes to examine for cortisol abnormalities and SCS. All collected salivary cortisol at 23:00 $\mathrm{h}$ and salivary and serum cortisol after a $1 \mathrm{mg}$ dexamethasone suppression test (DST). Patients whose results were in the upper quintile for each test $(253 \mathrm{ng} / \mathrm{dL}, 47 \mathrm{ng} / \mathrm{dL}$, and $1.8 \mu \mathrm{g} / \mathrm{dL}$, respectively for the $23: 00 \mathrm{~h}$ and post-DST saliva and serum cortisol) were re-investigated. Average values from the upper quintile group were 2.5fold higher than in the remaining patients. After a confirmatory $2 \mathrm{mg} \times 2$ day DST the investigation for CS was ended for 61 patients with all normal tests and 33 with only one (false) positive test. All 8 patients who had two abnormal tests had subsequent normal 24h-urinary cortisol, and 3 of them were likely to have SCS (abnormal cortisol tests and positive imaging). However, a final diagnosis could not to be confirmed by surgery or pathology. Although not confirmatory, the results of this study suggest that the prevalence of SCS is considerably higher in populations at risk than in the general population. (Arq Bras Endocrinol Metab 2007;51/7:1118-1127)

Keywords: Type 2 diabetes mellitus; Obesity; Overweight; Hypercortisolism; Cushing's syndrome; Subclinical Cushing's syndrome

\section{RESUMO}

Aumento da Probabilidade Diagnóstica de Síndrome de Cushing Subclínica em uma Amostra Populacional de Pacientes Adultos Obesos com Diabetes Mellitus Tipo 2.

A síndrome de Cushing (SC) endógena é rara. Pacientes com SC subclínica (SCS) apresentam hipercortisolismo sem manifestações clínicas. SC ocorre em 2-3\% de diabéticos mal controlados. Estudamos 103 pacientes adultos obesos ambulatoriais com diabetes mellitus tipo 2 para avaliar alterações do cortisol e SCS. Todos coletaram cortisol salivar às $23: 00 \mathrm{~h}$ e cortisol salivar e sérico após teste de supressão com $1 \mathrm{mg}$ de dexametasona (DST). Pacientes cujos resultados de qualquer teste estavam no quintil superior $(253 \mathrm{ng} / \mathrm{dL}, 47 \mathrm{ng} / \mathrm{dL}$ e 1,8 $\mu \mathrm{g} / \mathrm{dL}$, respectivamente para cortisol salivar 23:00 h e salivar e sérico pós-DST) foram reavaliados. Os valores médios desse grupo encontravam-se 2,5 vezes acima dos valores dos demais pacientes. Após um teste confirmatório com 2 $\mathrm{mg} \times 2$ dias DST, a investigação da SC foi encerrada para 61 pacientes com todos os testes normais e $33 \mathrm{com}$ apenas um teste (falso) positivo. Todos os 8 pacientes com dois testes alterados apresentaram cortisol urinário normal, mas 3 deles mostraram maior probabilidade diagnóstica de SCS (hipercortisolismo e alterações em exames de imagem). Contudo, o diagnóstico final não pode ser confirmado por cirurgia ou patologia em nenhum deles. Embora não confirmatórios, os resultados deste estudo sugerem que a prevalência de SCS seja maior em populações de risco do que na população geral. (Arq Bras Endocrinol Metab 2007;51/7:1118-1127)

Descritores: Diabetes mellitus tipo 2; Obesidade; Sobrepeso; Hipercortisolismo; Síndrome de Cushing; Síndrome de Cushing subclínica 
T HE WIDESPREAD USE OF POTENT synthetic glucocorticoid for a number of medical conditions is often associated with florid "cushingoid" manifestations. However, endogenous hypercortisolism or Cushing's syndrome (CS) is considered an unusual disorder (1).

Endogenous CS is due either to primary (adrenal) or secondary (hypothalamic-pituitary) causes, the most common of which $(80 \%)$ is "Cushing's disease", resulting from a corticotropin-secreting pituitary microadenoma. The cortisol-secreting adrenal adenoma, the second most common cause of CS, responds for less than $10 \%$ of the cases, although recent findings in reported series of adrenal incidentalomas point to a novel medical condition referred to as "subclinical CS" (3). In this setting, mildly altered cortisol dynamics is not associated with obvious clinical manifestations. In contrast, the metabolic syndrome resembles CS in several clinical aspects, but shares only a few abnormalities in cortisol dynamics.

The incidence of CS is estimated in 1:50,000 to 1:100,000 inhabitants of a general population $(1,2)$. However, the metabolic syndrome (4) as well as the adrenal incidentaloma (2) has been reported increasingly worldwide.

Thus, it is conceivable that the incidence of CS could be higher than previously reported, provided screening tests are aimed at specific populations at risk. In fact, Leibowitz et al. (5) and Catargi et al. (6) found incidences of $2.2 \%$ and $2 \%$ in respectively 153 and 200 obese poorly controlled diabetic patients.

Screening tests for the diagnosis of CS include: (1) late-night $(23: 00 \mathrm{~h})$ serum or saliva cortisol (to examine the absence of a circadian rhythm), (2) response to $1 \mathrm{mg}$ overnight dexamethasone suppression (to assess corticotroph resistance to the negative feedback), and (3) 24h-urinary free cortisol excretion rate (an indirect estimation of increased cortisol production) (6).

The former two tests are likely to be more sensitive in the detection of subclinical CS, in contrast to increased urinary free cortisol, that may be elevated only when clinical manifestations are present. Using appropriate cut-off values for greatest specificity, the sensitivity of these tests is generally acceptable to establish them as diagnostic standards for screening (7).

In CS, the frequency of obesity, glucose intolerance (with or without overt diabetes mellitus), and arterial hypertension reaches up to $90 \%$ of the patients (8-12). Nonetheless, each of these three features is highly prevalent worldwide (13-15).

Although mortality is already elevated in obese, diabetic, and/or hypertensive patients, it may be even higher in those with CS. When matched for age and gender, mortality of patients with SC was shown to be 4 -fold higher than in the general population, mostly due to cardiovascular disease $(16,17)$.

Medical and surgical cure or remission of the excess cortisol state in clinical or subclinical CS (adrenal incidentalomas) is associated with reduction in body mass and with significant improvement in glucose control and blood pressure levels $(17,18)$.

In this paper we investigate adult overweight patients with type 2 diabetes mellitus (DM2) routinely followed in the Diabetes Clinic of our Institution, to verify the extent and magnitude of the abnormalities in cortisol dynamics and, as a consequence, if patients may have undiagnosed or occult CS, that could benefit from proper treatment.

\section{PATIENTS AND METHODS}

We examined the medical charts of 285 sequential outpatients with DM2 who have been routinely followed in the Diabetes Center of the Division of Endocrinology at the Federal University of São Paulo, SP, Brazil. The diagnosis of DM2 has been previously established in all by current clinical, laboratory, and immunologic standards $(19,20)$.

Patients with the following criteria were excluded: (1) younger than 20 years of age, (2) BMI below $25 \mathrm{~kg} / \mathrm{m}^{2}$, (3) pregnancy and breast-feeding, (4) previous or ongoing diagnosis of endogenous Cushing's syndrome, depression, chronic renal, and/or hepatic insufficiency, and alcoholism, and (5) use of drugs that could potentially interfere with the diagnostic tests or laboratory assessment of cortisol, such as glucocorticoids, rifampicin, ketoconazole, carbamazepine, desmopressin, and mifepristone.

Of the 285 patient charts examined, 125 (44\%) fulfilled the inclusion criteria and patients were summoned for a preliminary interview. One hundred and three of them $(82.4 \%)-69$ female and 34 male, ranging from 36 to 82 years of age (median of 56) - agreed to participate in the protocol that had been previously approved by the Ethics Committee on Human Research from our Institution.

On a separate appointment, all 103 patients signed a written consent and were officially enrolled, having the following clinical and physical examination data compiled: time from initial diagnosis of DM2 and hypertension, if present, weight and height, waist and hip circumferences (to calculate the waist:hip ratio - WHR), arterial blood pressure (BP), and medicines being used. Recent routine laboratory tests (within the last 30 days) were assembled, in special serum glucose, glicated haemoglobin ( $\mathrm{HbAlc})$, total and fractionated cholesterol, total blood count, creatinine, and urinalysis.

All patients were told to maintain their regular activities and routine medicines and to remain fast after $22: 00 \mathrm{~h}$ on a specified day. At 23:00 h of that day they were instructed to 
collect saliva in a specific collector (Salivette ${ }^{\circledR}$, Sarstedt, Germany) after oral hygiene with filtered water, and to keep the material under refrigeration until the next morning. Immediately after the saliva collection they should take $1 \mathrm{mg}$ dexamethasone (DEX, 2 x $0.5 \mathrm{mg}$ Decadron ${ }^{\circledR}$ tablets, Prodome, Brazil) with half a glass of water. The next morning all patients were seen in the laboratory where they had blood and a second saliva sample drawn between 08:00 $\mathrm{h}$ and 09:00 h.

Free cortisol was measured in the saliva and total serum cortisol, DEX and glucose in the blood samples. Although serum DEX was initially assessed to confirm ingestion and to validate the $1 \mathrm{mg}$ overnight DEX suppression test (DST), its levels were subsequently used for correlation purposes.

Instead of using pre-established test cut-off values for selecting patients at risk for CS, we chose to call back every patient whose test results were within the upper quintile (P80) for each test. This procedure introduces a higher sensitivity and would permit the investigation of a greater number of suspicious patients, in especial those who were in the "grey zone" for dynamic tests.

\section{Additional testing / further investigation}

Except for six patients $(3 \mathrm{M} / 3 \mathrm{~F})$ who subsequently declined additional testing, all other 23 who did not suppress saliva (values $\geq 47 \mathrm{ng} / \mathrm{dL}$ ) and/or serum cortisol (values $\geq 1.8$ $\mu \mathrm{g} / \mathrm{dL}$ ) levels following a valid $1 \mathrm{mg}$ overnight DST (serum DEX > $157 \mathrm{ng} / \mathrm{dL}$ at 08:00 h, see below), and regardless of the 23:00 h saliva cortisol level, were summoned for further investigation. An additional test was then performed, consisting of the classic low-dose DST $(0.5 \mathrm{mg}$ DEX PO every 6 h for 8 doses) (21) in which blood samples were drawn before and 48 h later for serum cortisol and DEX.

From this point on, and despite the exclusive response to the classic low-dose DST, patients who had two abnormal test responses (elevated 23:00 h saliva cortisol and non-suppressible saliva or serum cortisol in response to either the $1 \mathrm{mg}$ overnight or the $2 \mathrm{mg}$ DST) proceed to further investigation for CS, which included: (a) measurement of plasma ACTH, (b) dehydroepiandrosterone sulfate (DHEAS), (c) a 24h-urinary free cortisol, and (d) a DDAVP stimulation test $\left(D_{D A V P}{ }^{\circledR}, 8 \mu \mathrm{g}\right.$ IV bolus, Ferring, Sweden), in which ACTH and cortisol were measured every 15 min for $2 \mathrm{~h}(21,22)$. Finally, all patients had an adrenal imaging performed with fine-cut computerized tomography (CT) scans and a pituitary magnetic resonance imaging.

Figure 1 illustrates the algorithm used to investigate CS in this particular at-risk population sample.

\section{Assays}

Saliva material was centrifuged at 2,000 rpm and together with serum samples was kept frozen until the respective assays. Salivary cortisol was measured in $25 \mu \mathrm{l}$ saliva aliquots by an inhouse radioimmunoassay (RIA) without previous extraction or chromatography, as previously described (23). In brief, the intra- and interassay coefficients of variation were $4.4 \%$ and $5.1 \%$, respectively, with a detection limit of $10 \mathrm{ng} / \mathrm{dL}$.
Serum cortisol was measured by an in-house RIA $(24,25)$. Serum DHEAS and plasma ACTH were also determined by commercially available chemiluminescent immunometric assay kits (Immulite ${ }^{\circledR} 2000$ DPC, USA) and urinary cortisol by a RIA kit (DSL-2100 Active ${ }^{\circledR}$ cortisol, USA). Serum DEX was measured by an in-house RIA as follows: $50 \mu \mathrm{l}$ of serum was added to rabbit anti-DEX antibodies (kindly provided by Dr. José Gilberto Vieira, Fleury Laboratory), and ${ }^{3} \mathrm{H}$-DEX tracer (Amersham, USA), and then incubated at $4^{\circ} \mathrm{C}$ for $12-16 \mathrm{~h}$. The tracer-antibody reaction was interrupted, free antibodies were separated with dextrancharcoal and radioactivity was measured in the supernatant with a $\beta$-counter. Intra- and interassay $\mathrm{CV}$ are $6.3 \%$ and $6.0 \%$, respectively, with the limit of sensitivity for that method set at $20 \mathrm{ng} / \mathrm{dL}$.

For statistical purposes all values below the limit of sensitivity for the particular assay were arbitrarily considered equal to the detection value divided by the square root of 2 (26).

\section{Screen tests cut-offs}

The P80 cut-off or threshold values (that separate patients in the upper quintile) for each screening test were, respectively: $253 \mathrm{ng} / \mathrm{dL}, 47 \mathrm{ng} / \mathrm{dL}$, and $1.8 \mu \mathrm{g} / \mathrm{dL}$, for the 23:00 h and the post- $1 \mathrm{mg}$ DST saliva, and the post- $1 \mathrm{mg}$ serum cortisol. The same $1.8 \mu \mathrm{g} / \mathrm{dL}$ threshold value was used for the post-2 mg DST.

Of note, these cut-offs values were close or similar to those previously reported to separate patients suspected to have CS from normal controls: $200 \mathrm{ng} / \mathrm{dL}(27)$ and 62 $\mathrm{ng} / \mathrm{dL}(28)$, respectively for the late-night $(23: 00 \mathrm{~h})$ and post- $1 \mathrm{mg}$ overnight DST saliva, and $1.8 \mu \mathrm{g} / \mathrm{dL}$ for the overnight $1 \mathrm{mg}(22)$ as well as for the low-dose $(2 \mathrm{mg} \times 2 \mathrm{~d}$ ) DST.

Therefore, for the purposes of the present study we considered saliva and cortisol levels that were equal or higher than the P80 threshold as "positive test results" for hypercortisolism.

The overnight $1 \mathrm{mg}$ and the $2 \mathrm{mg}$ x $2 \mathrm{~d}$ DST were validated whenever 08:00 h post-test serum DEX levels were $>157 \mathrm{ng} / \mathrm{dL}(95 \% \mathrm{CL})$.

\section{Statistical analysis}

Comparison between variables was performed using the Mann-Whitney U test and Student's t test, where appropriate. Correlation coefficients were determined by the Spearman test. The level of statistical significance was set at $5 \%$ (p $<0.05)$.

\section{RESULTS}

\section{Clinical characteristics of the population sample (table 1)}

Age, duration of DM2, BP, weight, BMI, WHR, and $\mathrm{HbAlc}$ from the 103 patients studied are presented in table 1 , according to gender. Male and female patients 


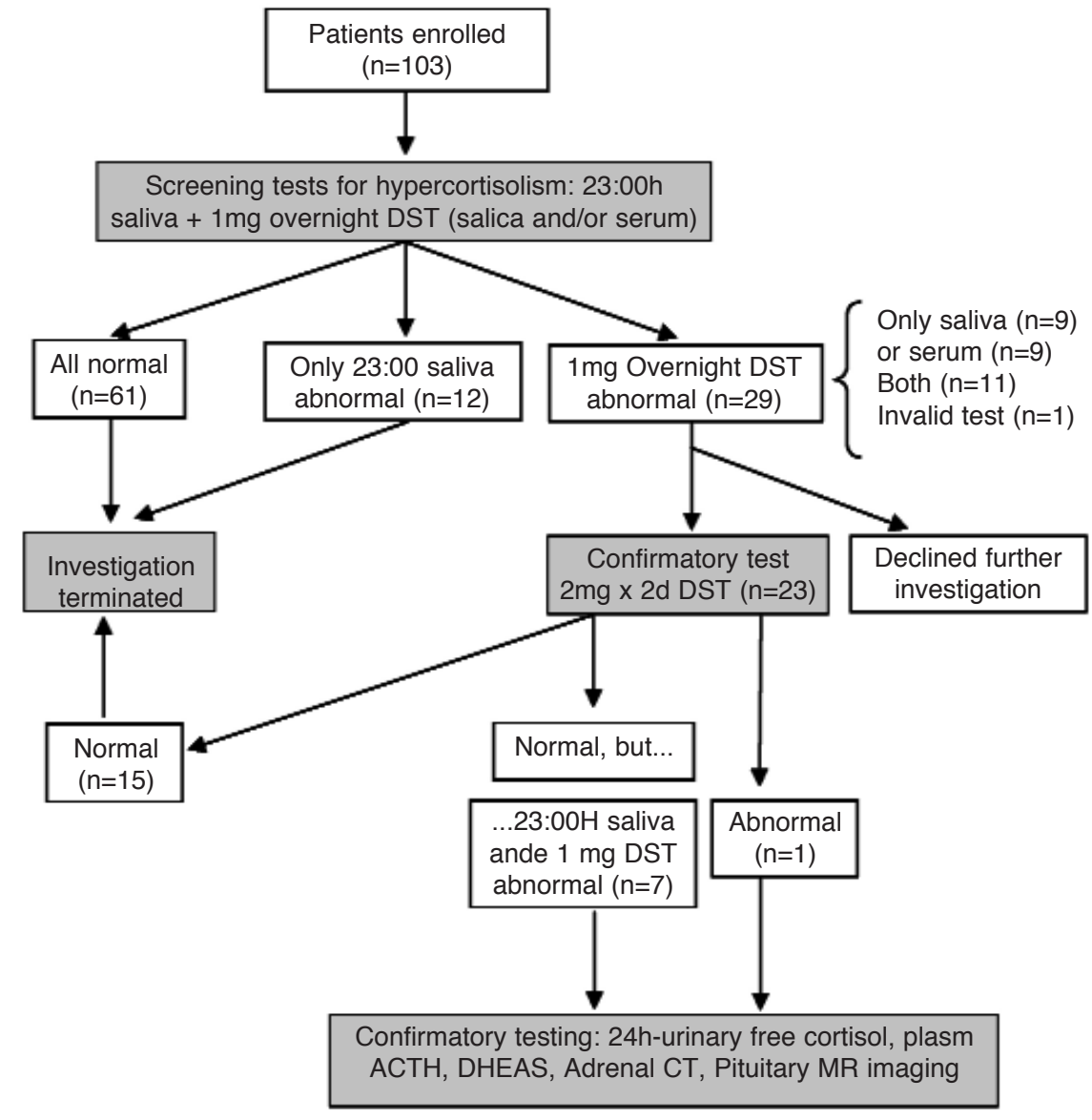

* $1 \mathrm{mg}$ Overnight DST is validated if serum DEX concentration $>157 \mathrm{ng} / \mathrm{dl}$

Figure 1. Algorithm used in the present series to screen overweight adult patients with DM2 for Cushing's syndrome.

Table 1. Clinical characteristics of the 103 patients studied, according to gender.

\begin{tabular}{|c|c|c|c|}
\hline & & \multicolumn{2}{|c|}{ Total of patients $(n=103 ; 34 \mathrm{M} / 69 \mathrm{~F}$} \\
\hline & & Mean \pm SD & Median [range] \\
\hline \multicolumn{2}{|l|}{ Age (y) } & $56.4 \pm 8.8$ & $56[36-82]$ \\
\hline \multicolumn{2}{|l|}{ Duration of DM (y) } & $10.8 \pm 7.5$ & $9[1-40]$ \\
\hline \multirow[t]{2}{*}{$\mathrm{BP}(\mathrm{mmHg})$ : } & Systolic & $149.5 \pm 23.2$ & 150 [110-220] \\
\hline & Diastolic & $92.3 \pm 13.9$ & $90[70-130]$ \\
\hline \multirow[t]{2}{*}{ Weight $(\mathrm{kg})$ : } & $\mathrm{M}$ & $85.7 \pm 16.3$ & $80.1[65.9-132]$ \\
\hline & $\mathrm{F}$ & $75.7 \pm 12.2^{*}$ & 74.0 [51.5-110] \\
\hline \multirow[t]{2}{*}{ BMI $\left(\mathrm{kg} / \mathrm{m}^{2}\right):$} & $\mathrm{M}$ & $30.5 \pm 5.1$ & $28.7[25.0-43.6]$ \\
\hline & $\mathrm{F}$ & $31.7 \pm 4.7$ & $31.4[25.1-48.9]$ \\
\hline \multirow[t]{2}{*}{ Waist circumfer. $(\mathrm{cm})$} & M & $102.4 \pm 12.0$ & $99[83-134]$ \\
\hline & $\mathrm{F}$ & $100.5 \pm 11.2$ & 100 [72-136] \\
\hline \multirow{2}{*}{ WHR: } & $\mathrm{M}$ & $0.99 \pm 0.05$ & $0.99[0.82-1.09]$ \\
\hline & $\mathrm{F}$ & $0.95 \pm 0.07^{* *}$ & $0.95[0.78-1.16]$ \\
\hline \multirow{2}{*}{ HbA1c (\%): } & $\mathrm{M}$ & $7.8 \pm 1.6$ & $7.6[5.3-12.0]$ \\
\hline & $\mathrm{F}$ & $9.0 \pm 2.3^{*}$ & $9.3[5.1-15.6]$ \\
\hline
\end{tabular}

* $\mathrm{P}<0.01, \mathrm{M}$ vs. $\mathrm{F}$ (Mann-Whitney's test)

** $P<0.005, M$ vs. $F$ (Student's t test) 
did not differ regarding age, duration of DM2, BMI, and waist circumference, although weight and the WHR were significantly higher in men.

Most of the patients $(81.5 \%$, being $79.4 \%$ male and $82.6 \%$ female) were already hypertensive at the beginning of the study; even on treatment the average systolic and diastolic BP were still elevated. Duration of hypertension varied from 1 to 41 years (median of 10). HbAlc was significantly higher in women.

\section{Hormonal values (table 2)}

Saliva (23:00 h and post- $1 \mathrm{mg}$ DST) and serum cortisol (post-1 - and post-2 mg DST) values are presented in table 2 as mean $( \pm S D)$ and median (range), as well as the P80. As previously defined, values $\geq$ P80 (upper quintile) for each test were considered "suspicious" for diagnostic purposes, in contrast to the "normal" ones (below the P80 value). In the upper quintile group, 23:00 $\mathrm{h}$ and post-1 $\mathrm{mg}$ DST saliva cortisol values ranged from 253 to 527 , and 47 to $117 \mathrm{ng} / \mathrm{dL}$, respectively, whereas post-1 $\mathrm{mg}$ DST serum cortisol ranged from 1.8 to $7.8 \mu \mathrm{g} / \mathrm{dL}$ (figure 2 ). Average values from the upper quintile group were approximately 2.5 - to 3 -fold higher than in the remaining $80 \%$ of patients. When patients in the upper quintile group were compared to the remaining ones for any of the three tests, there were no significant differences regarding age, BMI, waist circumference, WHR, and HbAlc. However, systolic and diastolic BP were significantly higher in the upper quintile group.

Since DM has been occasionally associated to abnormalities in the HHA axis, we compared the results of saliva and serum cortisol to serum glucose or HbAlc levels and found no correlation with the test results.
Because the serum cortisol cut-off of 1.8 $\mu \mathrm{g} / \mathrm{dL}$ used for the $1 \mathrm{mg}$ DST in the present study was similar to the value used systematically in the literature, we compared serum and saliva cortisol responses to $1 \mathrm{mg}$ DST using a 2 x 2 table: results were concordant in 84 patients $(73$ did suppress serum cortisol below $1.8 \mu \mathrm{g} / \mathrm{dL}$ and saliva cortisol below $47 \mathrm{ng} / \mathrm{dL}$, whereas 11 did not), and were discordant in 18, nine "false-positives' and nine "falsenegatives" (figure 3 ).

Therefore, when the cut-off value of $47 \mathrm{ng} / \mathrm{dL}$ was used to define a positive response for the $1 \mathrm{mg}$ DST saliva cortisol, as compared to the $1.8 \mu \mathrm{g} / \mathrm{dL}$ serum cortisol, we obtained a sensitivity of $57.1 \%$ and a specificity of $89 \%$ for this test. Even with such a small sensitivity this value is already clearly below values used by others (28).

Validation of the DST was ascertained by measuring concurrently obtained serum DEX levels at 08:00 h. Serum DEX levels ranged from 135 to 761 $\mathrm{ng} / \mathrm{dL}($ mean $\pm \mathrm{SD}$ of $346 \pm 122$; median of 340 ). Using a cut-off value for "positive" DEX levels set at $157 \mathrm{ng} / \mathrm{dL}(95 \% \mathrm{CI})$, only one (out of 103) $1 \mathrm{mg}$ DST was considered invalid and therefore excluded from statistical analysis. The $2 \mathrm{mg}$ x $2 \mathrm{~d}$ DST was not validated (DEX $<157 \mathrm{ng} / \mathrm{dL}$ ) in 3 of 4 patients who did not suppress serum cortisol levels; a normal and valid response was obtained in $19(82.6 \%)$ patients.

Table 3 shows the clinical data of patients subgrouped according to test results: 61 patients $(25 \% \mathrm{M} /$ $75 \% \mathrm{~F}$ ) had all 3 tests normal, 33 had only one (either a 23:00 h saliva cortisol $[\mathrm{n}=12]$ or a post- $1 \mathrm{mg}$ DST saliva or serum cortisol $[\mathrm{n}=2 \mathrm{l}]$ ) and eight had two abnormal test responses.

Table 2. Mean $( \pm S D)$, median (P50, and range), and $P 80$ values of cortisol determinations in saliva (23:00 $\mathrm{h}$ and 08:00 $\mathrm{h}$ after $1 \mathrm{mg} \mathrm{DST}$ ) and serum (after $1 \mathrm{mg}$ and $2 \mathrm{mg} \mathrm{DST}$ ).

\begin{tabular}{|c|c|c|c|}
\hline & Mean \pm SD & P50 or Median [range] & P80 \\
\hline 23:00 h Saliva $(n=103)$ & $172.3 \pm 101.9$ & $154[29.5-527.1]$ & 253 \\
\hline$\geq \mathrm{P} 80$ & $339.9 \pm 77.6$ & & \\
\hline$<\mathrm{P} 80$ & $129.3 \pm 49.4$ & & \\
\hline \multicolumn{4}{|l|}{$1 \mathrm{mg}$ Overnight DST } \\
\hline Saliva $(n=102)^{*}$ & $30.4 \pm 24.1$ & $26.8[7-117]$ & 47 \\
\hline$\geq \mathrm{P} 80$ & $69 \pm 22.6$ & & \\
\hline$<\mathrm{P} 80$ & $21 \pm 12.1$ & & \\
\hline Serum $(n=102)^{*}$ & $1.4 \pm 0.9$ & $1.2[0.4-7.8]$ & 1.8 \\
\hline$\geq \mathrm{P} 80$ & $2.6 \pm 1.4$ & & \\
\hline$<\mathrm{P} 80$ & $1.1 \pm 0.3$ & & \\
\hline $2 \mathrm{mg} \times 2$ day DST $(\mathrm{n}=20)^{\#}$ & & $0.9[0.3-2.6]$ & 1.8 \\
\hline$\geq P 80(n=1)$ & 2.6 & & \\
\hline$<P 80(n=19)$ & $0.8 \pm 0.4$ & & \\
\hline
\end{tabular}

* One and ${ }^{\#}$ Three false-positive tests were excluded (invalid). 


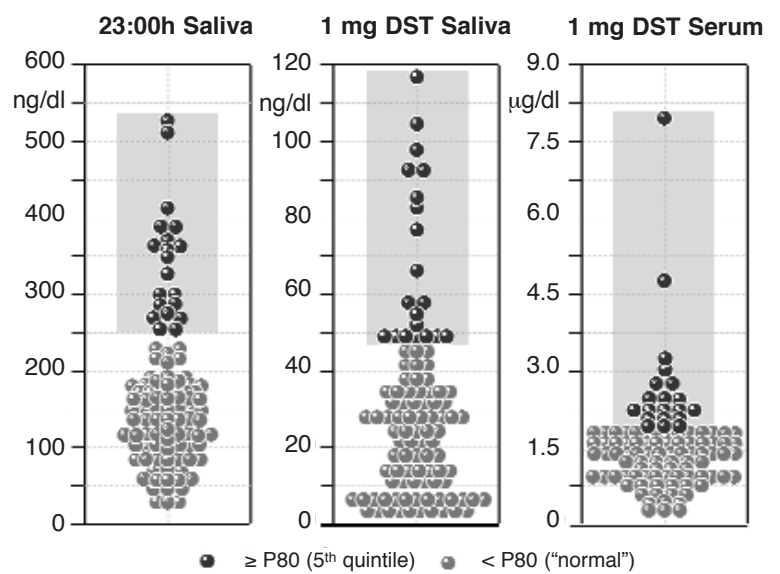

Figure 2. Saliva and serum cortisol levels in adult overweight DM2 patients evaluated for Cushing's syndrome. The shaded areas include values from patients who were in the upper quintile for each screening test (above the P80 thresholds that were respectively: $253 \mathrm{ng} / \mathrm{dL}, 47 \mathrm{ng} / \mathrm{dL}$, and $1.8 \mu \mathrm{g} / \mathrm{dL}$, for the 23:00 $\mathrm{h}$ and the post-1 $\mathrm{mg}$ DST saliva, and the post-1 mg DST serum cortisol). Values in the shaded areas were considered suspicious for endogenous hypercortisolism.

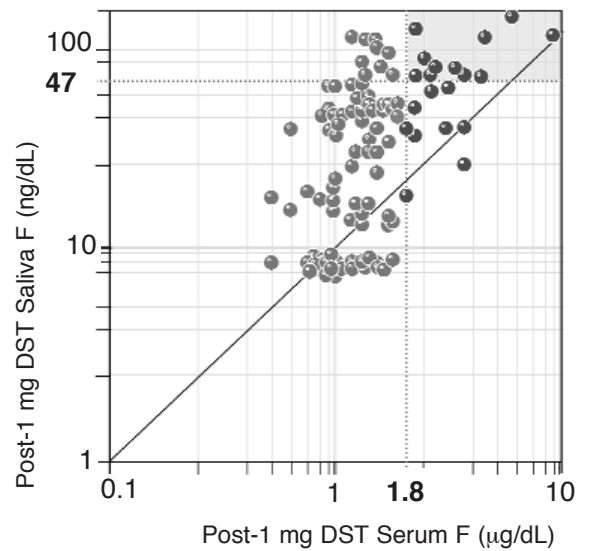

Figure 3. Correlation of concurrent serum and saliva cortisol levels after $1 \mathrm{mg}$ DST. Individual pairs of post-DST serum and saliva cortisol levels were concordant in 84 patients (placed in the upper right and the lower left quadrants).

Table 3. Clinical characteristics of the overweight diabetic patients grouped according to their responses to the functional tests for Cushing's syndrome: all normal ( $\mathrm{n}=$ $61)$, one $(n=33)$ and two $(n=8)$ abnormal tests.

\begin{tabular}{|c|c|c|c|c|c|c|c|c|}
\hline & \multirow{2}{*}{\multicolumn{2}{|c|}{ All normal $(n=61)$}} & \multicolumn{4}{|c|}{ One abnormal test $(n=33)$} & \multicolumn{2}{|c|}{ Two abnormal tests $(n=8)$} \\
\hline & & & \multicolumn{2}{|c|}{$\begin{array}{l}\text { Salivary cortisol 23:00 } \\
\quad h(n=12)\end{array}$} & \multicolumn{2}{|c|}{$\begin{array}{l}\text { Salivary or serum cortisol } \\
\text { post-1 } \mathrm{mg} \text { DST }(\mathrm{n}=21)\end{array}$} & \multirow{2}{*}{ I wo abnorn } & \multirow[b]{2}{*}{ Median } \\
\hline & Mean & Median & Mean & Median & Mean & Median & & \\
\hline Age $(y)$ & $55.8 \pm 8$ & $56[38-75]$ & $54.3 \pm 9.4$ & $53.5[42-67]$ & $59.5 \pm 8.8$ & $58[43-82]$ & $53.3 \pm 10.3$ & $55.5[36-67]$ \\
\hline Years of DM & $10.7 \pm 7.7$ & $9[2-40]$ & $11.8 \pm 7.6$ & $9[3-26]$ & $11.0 \pm 6.2$ & $11[2-22]$ & $10.1 \pm 10.1$ & $7[1-34]$ \\
\hline Weight (kg) & $78.1 \pm 14.2$ & $75.8[51.5-110.5]$ & $78 \pm 13.6$ & $75.6[61.3-112.6]$ & $81.9 \pm 15.4$ & $79.8[63.5-132]$ & $82.1 \pm 15.2$ & $76.9[67.8-115.4]$ \\
\hline BMI $\left(\mathrm{kg} / \mathrm{m}^{2}\right)$ & $31.3 \pm 4.9$ & 30.3 [25-48.9] & $31.4 \pm 4.9$ & $30.3[25.7-40.9]$ & $31.7 \pm 4.9$ & $30.8[25.7-43.6]$ & $31.2 \pm 4.4$ & $30.9[25.5-38.1]$ \\
\hline Waist $(\mathrm{cm})$ & $100.9 \pm 11.2$ & $101[80-136]$ & $102.9 \pm 7.6$ & $101[92-120]$ & $101.5 \pm 13.0$ & $99[83-104]$ & $102.5 \pm 10.8$ & $99[91-124]$ \\
\hline WHR & $0.96 \pm 0.07$ & $0.96[0.78-1.11]$ & $0.97 \pm 0.05$ & $0.98[0.87-1.06]$ & $0.96 \pm 0.08$ & $0.98[0.82-1.16]$ & $0.97 \pm 0.06$ & $0.98[0.89-1.04]$ \\
\hline $\mathrm{SBP}(\mathrm{mmHg})$ & $145.9 \pm 21.5$ & $140[110-200]$ & $142.5 \pm 20.9$ & $135[120-180]$ & $160 \pm 22.8$ & $160[130-210]$ & $160 \pm 32.1$ & $155[120-220]$ \\
\hline $\mathrm{DBP}(\mathrm{mmHg})$ & $89.7 \pm 11.2$ & $90[70-110]$ & $88.3 \pm 15.3$ & $90[70-110]$ & $100.5 \pm 16$ & $100[80-130]$ & $96.3 \pm 18.5$ & $100[70-120]$ \\
\hline HbA1c (\%) & $8.7 \pm 2.3$ & $8.4[5.1-15.6]$ & $8.3 \pm 1.5$ & $8.8[5.3-9.9]$ & $8.8 \pm 1.8$ & $9.4[6.0-12.5]$ & $7.8 \pm 2.7$ & $6.9[6.2-14.4]$ \\
\hline Glicemia (mg/dL) & $151.2 \pm 74$ & $132[53-488]$ & $135.5 \pm 49.7$ & $122[58-223]$ & $158 \pm 56.9$ & $144[93-365]$ & $134.5 \pm 40.7$ & $128[74-192]$ \\
\hline $\begin{array}{l}\text { 23:00 h Saliva } \\
F(n g / d L)\end{array}$ & $122.5 \pm 46.5$ & $117[30-212.1]$ & $325.9 \pm 76.7$ & 299.4 [253-512] & $149.2 \pm 53.4$ & $156[29.5-232.7]$ & $367.3 \pm 79.9$ & $370.5[264-527.1]$ \\
\hline $\begin{array}{l}1 \mathrm{mg}-\mathrm{DST} \\
\text { Saliva (ng/dL) }\end{array}$ & $20.2 \pm 11.8$ & $17.5[7-46]$ & $18.5 \pm 14$ & $13[7-46]$ & $54.1 \pm 23.9$ & 49 [16-105] & $63.8 \pm 34$ & $58.3[20.1-117]$ \\
\hline $\begin{array}{l}1 \mathrm{mg}-\mathrm{DST} \\
\text { Serum }(\mu \mathrm{g} / \mathrm{dL})\end{array}$ & $1.1 \pm 0.3$ & $1.1[0.4-1.7]$ & $1.1 \pm 0.4$ & $1.2[0.4-1.7]$ & $1.9 \pm 0.6$ & $1.9[1.1-3.2]$ & $3.1 \pm 2.2$ & $2.4[1.3-7.8]$ \\
\hline $\mathrm{DEX}(\mathrm{ng} / \mathrm{dL})$ & $348.2 \pm 128.5$ & 339 [140-761] & $333.4 \pm 135.2$ & 345 [159-660] & $359.7 \pm 96$ & $356[165-514]$ & $311.4 \pm 126.9$ & $314[135-476]$ \\
\hline
\end{tabular}

\section{Patients with likely "endogenous hypercor- tisolism"}

Eight patients $(4 \mathrm{M} / 4 \mathrm{~F})$ had a tentative diagnosis of endogenous hypercortisolism made, due to a combination of elevated 23:00 h saliva cortisol levels, and non-suppressible saliva or serum cortisol levels to $1 \mathrm{mg}$ and/or $2 \mathrm{mg}$ DST.

Individual clinical data and hormonal results for these eight patients are depicted in table 4. In all, a subsequent $24 \mathrm{~h}$-urinary free cortisol sample gave nor- mal results, whereas basal plasma ACTH levels were subnormal $(<10 \mathrm{pg} / \mathrm{mL})$ in one (with serum DHEAS also subnormal), low-normal $(10-20 \mathrm{pg} / \mathrm{mL})$ in five (with serum DHEAS subnormal in one) and $>20$ $\mathrm{pg} / \mathrm{mL}$ in two (both with normal DHEAS).

ACTH was unresponsive to a DDAVP stimulation test in six, four of whom had normal pituitary MR and adrenal CT imaging (table 4).

Four patients were diagnosed as having bilateral adrenal hyperplasia $(\mathrm{BAH})$ on adrenal CT, one of 


\begin{tabular}{|c|c|c|c|c|c|c|c|c|c|c|c|c|c|c|c|c|c|}
\hline \multirow[t]{2}{*}{ ID } & \multirow{2}{*}{$\begin{array}{l}\text { Sex/ } \\
\text { age }\end{array}$} & \multirow{2}{*}{$\begin{array}{l}\text { Years } \\
\text { of DM }\end{array}$} & \multirow[t]{2}{*}{ BMI } & \multirow[t]{2}{*}{ Waist } & \multirow[t]{2}{*}{ WHR } & \multirow[t]{2}{*}{$\uparrow \mathbf{B P}$} & \multirow[t]{2}{*}{ HbA1c } & \multicolumn{4}{|c|}{ Cortisol } & \multirow[t]{2}{*}{ АСтн } & \multirow[t]{2}{*}{ DHEAS } & \multirow[t]{2}{*}{ FU } & \multirow{2}{*}{$\begin{array}{c}\text { DDAVP } \\
\text { CT }\end{array}$} & \multirow{2}{*}{$\begin{array}{c}\text { Adrenal } \\
\text { MR }\end{array}$} & \multirow[t]{2}{*}{ Pituitary } \\
\hline & & & & & & & & $\begin{array}{l}\text { Saliva } \\
\text { 23:00 }\end{array}$ & $\begin{array}{l}\text { Saliva } \\
1 \mathrm{mg}\end{array}$ & $\begin{array}{c}\text { Serum } \\
1 \mathrm{mg}\end{array}$ & $\begin{array}{l}\text { Serum } \\
2 \mathrm{mg}\end{array}$ & & & & & & \\
\hline A & F 36 & 5 & 32.3 & 98 & 1.04 & Yes & 7.0 & 264 & 20.1 & 2.7 & * & 12.0 & 162 & 65 & - & $\mathrm{NI}$ & $\mathrm{NI}$ \\
\hline B & $\mathrm{F} 43$ & 11 & 29.6 & 94 & 0.92 & Yes & 14.4 & 371 & 48.7 & 2.1 & 0.9 & 28.3 & 97 & 50 & + & $\begin{array}{c}\text { BAH+ } \\
\text { Nodule }\end{array}$ & $\mathrm{NI}$ \\
\hline C & F 56 & 6 & 33.1 & 100 & 1.00 & Yes & 7.8 & 283 & 27 & 2.7 & 1 & 13.7 & 40 & 73 & - & $\mathrm{NI}$ & $\mathrm{NI}$ \\
\hline D & F 67 & 34 & 36.0 & 113 & 0.89 & Yes & 6.8 & 391 & 117 & 4.7 & 2.6 & 8.6 & 11 & 172 & - & $\mathrm{BAH}$ & $\begin{array}{l}\text { Empty } \\
\text { sella }\end{array}$ \\
\hline E & M 48 & 8 & 27.1 & 98 & 1.01 & No & 6.2 & 527 & 66.5 & 1.6 & 0.9 & 15.0 & 15 & 183 & - & BAH & $\mathrm{NI}$ \\
\hline $\mathrm{F}$ & M 55 & 6 & 38.1 & 124 & 0.95 & Yes & 6.2 & 370 & 98 & 7.8 & 0.7 & 36.6 & 67 & 75 & - & $\mathrm{NI}$ & $\mathrm{NI}$ \\
\hline G & M 59 & 10 & 28.1 & 102 & 1.02 & Yes & 7.3 & 346 & 50 & 1.9 & 0.3 & 7.9 & 122 & 64 & - & $\mathrm{NI}$ & $\mathrm{NI}$ \\
\hline $\mathrm{H}$ & M 62 & 1 & 25.5 & 91 & 0.92 & No & 6.3 & 386 & 83.4 & 1.3 & 0.9 & 12.8 & 178 & 82 & + & $\mathrm{BAH}$ & $\begin{array}{c}6 \mathrm{~mm} \\
\text { nodule }\end{array}$ \\
\hline
\end{tabular}

* Invalid test

whom with an additional $0.8 \mathrm{~cm}$ left adrenal nodule: one with an empty sella, one with a 5-6 mm sellar nodule, and two with normal pituitary MR imaging.

The overall analysis of plasma ACTH, urinary free cortisol, serum DHEAS, and DDAVP stimulation test, together with negative adrenal and pituitary imaging, made the probability of diagnosing CS in five of those eight patients rather slim.

The final three patients (\# B, D, and $\mathrm{H}$, in table 4) were likely to have subclinical CS, but in none this diagnosis could be surgically and/or pathologically confirmed so far. Patient B has bilateral adrenal hyperplasia $(\mathrm{BAH})$ and an adrenal nodule, ACTH > 20 $\mathrm{pg} / \mathrm{mL}$ and a positive response to DDAVP, but has an unremarkable pituitary MR imaging. Although this may occur in up to $40 \%$ of patients with Cushing's disease $(29,30)$, she declined inferior petrosal sinus sampling (IPSS) and has been followed clinically ever since.

Patient $\mathrm{H}$ has $\mathrm{BAH}$ with a $6 \mathrm{~mm}$ pituitary nodule identified by MR. He also declined IPSS and subsequent surgery, if ever indicated.

Patient D is the most likely to present CS: she has BAH with an empty sella, repeatedly non-suppressible serum cortisol levels, but undetectable and DDAVP-unresponsive ACTH values. Partial investigation for macronodular adrenal hyperplasia resulted inconclusive, and a definite diagnosis could not yet be established.

\section{DISCUSSION}

Among the classical manifestations of cortisol excess in CS, central obesity, glucose intolerance, and arterial hypertension predominate. These features are also characteristic of the metabolic syndrome, a highly prevalent condition among the general population. The elevated mortality observed in patients with CS is not only associated to cardiovascular events $(16,17)$, but also to the period of exposure to cortisol excess (31).

Adult overweight type 2 diabetic patients, as in the case of the present study, also have a high prevalence of hypertension, being a distinctive risk group for the occurrence of CS.

The algorithm applied to investigate the extent and magnitude of cortisol abnormalities (figure 1) was a logical one in trying to screen and uncover patients who may have occult or undiagnosed CS. Using latenight saliva followed by the $1 \mathrm{mg}$ overnight DST, and measuring serum and saliva cortisol the next morning, we were able to exclude almost $60 \%$ of the patients in whom all results came back normal (below the P80 cut-off value for each test). By doing this we restricted the investigation to the most suspicious upper quintile subgroup, running only a minor risk of missing patients with CS but with false-negative results. In addition, because 23:00 h saliva cortisol was considered the least robust among the screening procedures (28), we also excluded 12 additional patients in whom this was the only abnormal result, raising to $72 \%$ the total of patients initially excluded.

Except for post-DST saliva cortisol, the threshold values established in the present series - by choosing the P80 value for each test - were close or even similar to those reported in the literature, that were most likely defined by ROC curves. Values for the 08:00 h saliva cortisol after overnight DST have been previously reported by Castro et al. (28), who defined different cut-off values according to the BMI: 62 and $392 \mathrm{ng} / \mathrm{dL}$, respectively for non-obese and obese subjects. Although all of our patients were overweight by the inclusion criteria $\left(\mathrm{BMI} \geq 25 \mathrm{~kg} / \mathrm{m}^{2}\right)$, the P80 cutoff value of $47 \mathrm{ng} / \mathrm{dL}$ for post-DST saliva cortisol was way below that proposed by Castro in the non-obese (28), presumably increasing test sensitivity. 
Because the cut-off value for post-DST serum cortisol (considered our gold-standard test) was already highly sensitive $(1.8 \mu \mathrm{g} / \mathrm{dL})$, in accordance with that for the post-DST saliva cortisol $(47 \mathrm{ng} / \mathrm{dL})$, individual pairs of post-DST serum and saliva cortisol, which correlate positive and significantly, were concordant in $82.4 \%$ of the validated tests.

From the 29 out of the 103 original patients $(28 \%)$, six declined further investigation. Also, from the remaining 23 patients $(22 \%), 15$ who had previously normal 23:00 h saliva cortisol levels had their investigation terminated since responded normally to a confirmatory $2 \mathrm{mg}$ x 2 d DST.

Thus, further detailed investigation was conducted only in the eight remaining patients who had at least two positive test results. When compared to patients who had normal responses to all tests and those with only one abnormal result, these eight patients did not disclose any particular clinical difference, except for being more hypertensive than the first group. Both serum glucose and HbAlc levels were similar, if not lower, than the other two groups. As expected for what is considered unsuspected or subclinical disease, only hormonal testing was abnormal (3234).

Five of these eight patients were subsequently excluded due to normal ACTH, urinary free cortisol, serum DHEAS, and DDAVP stimulation test. Also adrenal and pituitary imaging were unremarkable. The final three patients (\# B, D, and $\mathrm{H}$, in table 4) were defined as subclinical CS. Because surgery or pharmacologic adrenalectomy was not attempted in any of them, we were able to follow them critically for the past two years. In none clinical manifestations of Cushing's syndrome ever became evident. In adrenal incidentalomas, progression of subclinical to overt CS is questionable, but probably occurs only occasionally (35).

Each patient from the original series who had only one abnormal test response was tentatively considered a false-positive for that test. In previous publications, functional abnormalities in the hypothalamicpituitary-adrenal (HPA) axis were vaguely associated to the presence of obesity (36), hypertension (37), and diabetes mellitus $(37,38)$. Most of these features were present in over $70 \%$ of our patients, and could easily explain some of the false-positive values, even in those who had two abnormal test results but in whom both adrenal and pituitary imaging were unrevealing.

However, this is still contradictory and open to discussion. We have previously demonstrated that obesity is not a cause of false-positive results for the $1 \mathrm{mg}$ overnight DST, although a cut-off level of $5 \mu \mathrm{g} / \mathrm{dL}$ was used at that time to define cortisol suppressibility (39). Others have found similar results (40). In the present study we also corroborate previous results (6) in that poorly-controlled diabetes may not make patients more prone to biochemical abnormalities in the HPA axis. Possible correlations between HbAlc levels or the presence of hypertension with the responses to each of the tests used were lacking in our study.

In addition, we have attempted to exclude falsepositive results in response to the DST by measuring serum dexamethasone levels. A serum concentration greater than $157 \mathrm{ng} / \mathrm{dL}$ was required for proper validation of the test. Similar results $(220 \mathrm{ng} / \mathrm{dL})$ were reported by others (4l).

Absence of the circadian cortisol rhythm is generally considered the weakest among the screening tests for CS (42). This is due to the fact that several diseases and/or clinical conditions may be associated with a lack of cortisol decay towards the evening, in special depressive disorders (in whom the response to DST may also be positive), aging, and the presence of hypertension and/or diabetes (37). However, latenight salivary cortisol levels were reasonably sensitive and specific (92\% and 93\%, respectively) in discriminating patients with $\mathrm{CS}$, from pseudo-CS, obese and non-obese control subjects (43). Also, in a recent review, Findling and Raff (44) suggest that 23:00 h salivary cortisol, drawn in two different occasions, may be the best approach to screen patients for CS.

In reported series of patients with an adrenal incidentaloma and subclinical CS, the absence of clinical manifestations is justified by normal cortisol production rates (35). This can be reflected by the normal 24h-urinary free cortisol levels observed in our patients.

Finally, taken altogether the results of the present study were very suggestive, although not confirmatory, that the prevalence of CS, in its subclinical form, is significantly higher in populations at risk for the disorder than in the general population, as previously observed by Leibowitz et al. (5) and Catargi et al. (6). Although current recommendations advise that only poorly controlled diabetic patients should be investigated for subclinical CS, two out of our three most distinctive candidates for this diagnosis had reasonably controlled DM2.

It is also worth to mention that although subclinical CS is typical of patients with an adrenal incidentaloma, hypothalamic-pituitary disease may also be found incidentally, as possibly suggested in two of our patients. 


\section{ACKNOWLEDGEMENTS}

We are indebted to Dr. Sergio A. Dib, director of the Diabetes Clinic, for kind assistance with the patients, to Ms. Lilian F. Hayashi and Kelly Cristina de Oliveira for excellent technical assistance, and to Dr. Suzan M. Goldman for skillful interpretation of adrenal and pituitary imaging.

\section{REFERENCES}

1. Ross NS. Epidemiology of Cushing's syndrome and subclinical disease. Endocrinol Metab Clin North Am 1994;23:539-46.

2. Boscaro M, Barzon L, Fallo F, Sonino N. Cushing's syndrome. Lancet 2001;357:783-91.

3. Terzolo M, Pia A, Ali A, Osella G, Bovio S, Angeli A, et al. Adrenal incidentaloma: a new cause of the metabolic syndrome? J Clin Endocrinol Metab 2002;87(3):998-1003.

4. Laaksonen DE, Niskanen L, Lakka HM. Epidemiology and treatment of the metabolic syndrome. Ann Med 2004:36:332-46.

5. Leibowitz G, Tsur A, Chayen SD, Salameh M, Raz I, Cerasi E, et al. Pre-clinical Cushing's syndrome: an unexpected frequent cause of poor glycaemic control in obese diabetic patients. Clin Endocrinol (Oxf) 1996;44:717-22.

6. Catargi B, Rigalleau V, Poussin A, Ronci-Chaix N, Bex V, Tabarin $A$, et al. Occult Cushing's syndrome in type-2 diabetes. J Clin Endocrinol Metab 2003;88:5808-13.

7. Findling JW, Raff H. Screening and diagnosis of Cushing's syndrome. Endocrinol Metab Clin North Am 2005; $34: 385-402$

8. Ross EJ, Linch DC. Cushing's syndrome - killing disease: discriminatory value of sign and symptoms aiding early diagnosis. Lancet 1982;2:646-9.

9. Urbanic RC, George JM. Cushing's disease - 18 years' experience. Medicine (Baltimore) 1981;60:14-24.

10. Soffer LJ, lannaccone A, Gabrilove JL. Cushing's syndrome: A study of fifty patients. Am J Med 1961;300:129-35.

11. Sprague RG, Randall RV, Salassa RM, Scholz DA, Priestley JT, Walters W, et al. Cushing's syndrome: A progressive and often fatal disease. Arch Intern Med 1956:98:389-98.

12. Plotz CM, Knowlton Al, Ragan C. The natural history of Cushing's syndrome. Am J Med 1956;13:597-614.

13. Malerbi DA, Franco LJ. Multicenter study of the prevalence of diabetes mellitus and impaired glucose tolerance in the urban Brazilian population aged 30-69 yr. Diabetes Care 1992;15(11):1509-16.

14. King $\mathrm{H}$, Aubert RE, Herman WH. Global burden of diabetes, 1995-2025. Diabetes Care 1998;21(9):1414-31.

15. Winer N, Sowers JR. Epidemiology of diabetes. J Clin Pharmacol 2004:44:397-405.

16. Mantero F, Boscaro M. Glucocorticoid-dependent hypertension. J Steroid Biochem Mol Biol 1992;43(5):409-13.

17. Arnaldi G, Masini AM, Giacchetti G, Taccaliti A, Faloia E, Mantero F. Adrenal incidentaloma. Braz J Med Biol Res 2000;33(10):1177-89

18. Rossi R, Tauchmanova L, Luciano A, Martino MD, Nuzzo V Lombardi G, et al. Subclinical Cushing's syndrome in patients with adrenal incidentalomas: clinical and biochemical features. J Clin Endocrinol Metab 2000;85(4):1440-8.

19. Gross JL, Silveiro SP, Camargo JL, Reichelt AJ, Azevedo MJ. Diabetes melito: diagnóstico, classificação e avaliação do controle glicêmico. Arq Bras Endocrinol Metab 2000;46:16-26.

20. American Diabetes Association. Diagnosis and classification of diabetes mellitus (position statements). Diabetes Care 2005;28(suppl.1):S37-S42.
21. Newell-Price J, Trainer P, Besser M, Grossman A. The diagnosis and differential diagnosis of Cushing's syndrome and pseudo-Cushing's states. Endocr Rev 1998;19:647-72.

22. Arnaldi G, Angeli A, Atkinson AB, Bertagna X, Cavagnini F, Chrousos GP, et al. Diagnosis and complications of Cushing's syndrome: a consensus statement. J Clin Endocrinol Metab 2003;88:5593-602

23. Vieira JGH, Noguti KO, Hidal JT, Russo EMK, Maciel RMB. Ensaio do cortisol na saliva como método para a avaliação da fração livre sérica. Arq Bras Endocrinol Metab 1984;28:810

24. Vieira JGH, Russo EMK, Germeck OA, Antunes LAN. Método radioimunológico para a dosagem de cortisol sérico. Rev Bras Patol Clin 1979;15:125-30.

25. Kater C, Vieira JGH, Furlanetto RP, Chacra AR, Lima MPC. Determinação do cortisol sérico por radioimunoensaio e sua aplicação no diagnóstico da síndrome de Cushing. Arq Bras Endocrinol Metab 1979;23:155-61.

26. Tonetto-Fernandes $\mathrm{V}$, Lemos-Marini SHV Kuperman $\mathrm{H}$ Ribeiro-Neto LM, Verreschi ITN, Kater CE. Serum 21-deoxycortisol, 17-hydroxyprogesterone, and 11-deoxycortisol in classic congenital adrenal hyperplasia: clinical and hormonal correlations and identification of patients with $11 \beta$-hydroxylase deficiency among a large group with alleged 21-hydroxylase deficiency. J Clin Endocrinol Metab 2006:91(6):2179-84.

27. Yaneva M, Mosnier-Pudar H, Dugue M-A, Grabar S, Fulla Y, Bertagna X. Midnight salivary cortisol for the initial diagnosis of Cushing's syndrome of various causes. J Clin Endocrinol Metab 2004:89:3345-51.

28. Castro M, Elias PC, Quidute AR, Halah FP, Moreira AC. Outpatient screening for Cushing's syndrome: the sensitivity of combination of circadian rhythm and overnight dexamethasone suppression salivary cortisol tests. J Clin Endocrinol Metab 1999;84:878-82.

29. Invitti C, Giraldi FP, de Martin M, Cavagnini F. Diagnosis and management of Cushing's syndrome: results of an Italian multicentre study group of the Italian Society of Endocrinology on the pathophysiology of the hypothalamic-pituitaryadrenal axis. J Clin Endocrinol Metab 1999;84:440-8.

30. Tabarin A, Laurent F, Catargi B, Olivier-Puel F, Roger P, Guerin J, et al. Comparative evaluation of conventional and dynamic magnetic resonance imaging of the pituitary gland for the diagnosis of Cushing's disease. Clin Endocrinol (Oxf) 1998;49:293-300.

31. Dekkers OM, Biermasz NR, Pereira AM, Roelfsema $F$, van Aken $\mathrm{MO}$, Voormolen $\mathrm{JHC}$, et al. Mortality in patients treated for Cushing's disease is increased, compared with patients treated for nonfunctioning pituitary macroadenoma. J Clin Endocrinol Metab 2007:92:976-81.

32. Sippel R, Chen H. Subclinical Cushing's syndrome. Surg Clin N Am 2004;84:875-85.

33. Barzon L, Sonino N, Fallo F, Palu G, Boscaro M. Prevalence and natural history of adrenal incidentalomas. Eur $\mathbf{J}$ Endocrinol 2003;149:273-85.

34. Terzolo M, Bovio S, Reimondo G, Pia Anna, Osella G, Borretta $G$, et al. Subclinical Cushing's syndrome in adrenal incidentalomas. Endocrinol Metab Clin North Am 2005;34:423-39.

35. Terzolo M, Reimondo G, Bovio S, Angeli A. Subclinical Cushing's syndrome. Pituitary 2004;7:217-23.

36. Godoy-Matos AF, Moreira RO, Guedes EP. Aspectos neuroendócrinos da síndrome metabólica. Arq Bras Endocrinol Metab 2003:47:410-21.

37. Liu H, Bravata DM, Cabaccan J, Raff H, Ryzen E. Elevated latenight salivary cortisol levels in elderly male type 2 diabetic veterans. Clin Endocrinol (Oxf) 2005;63:642-9.

38. Cameron OG, Kronfol Z, Greden JF, Carroll BJ. Hypothalamic-pituitary-adrenocortical activity in patients with diabetes mellitus. Arch Gen Psychiatry 1984;41:1090-5.

39. Vieira JGH, Accursio W, Russo EMK, Maciel RMB, Kater CE, Chacra AR. Estudo do valor do teste rápido de supressão com dexametasona na triagem de pacientes suspeitos de síndrome de Cushing. Rev Assoc Med Bras 1985;31:129-32. 
40. Wood PJ, Barth JH, Friedman DB, Perry L, Sheridan B. Evidence for the low dose dexamethasone suppression to screen for Cushing's syndrome - recommendations for a protocol for biochemistry laboratories. Ann Clin Biochem 1997;34:222-9.

41. Weiner MF. Age and cortisol suppression by dexamethasone in normal subjects. J Psychiat Res 1989;23:163-8.

42. Papanicolaou DA, Mullen N, Kyrou I, Nieman LK. Nighttime salivary cortisol: a useful test for the diagnosis of Cushing's syndrome. J Clin Endocrinol Metab 2002;87:4515-21.

43. Putignano P, Toja P, Dubini A, Giraldi FP, Corsello SM, Cavagnini $F$. Midnight salivary cortisol versus urinary free and midnight serum cortisol as screening tests for Cushing's syndrome. J Clin Endocrinol Metab 2003;88:4153-7.
44. Findling JW, Raff H. Clinical review: Cushing's syndrome. J Clin Endocrinol Metab 2006;91(10):3746-53.

Endereço para correspondência:

\section{Claudio E. Kater}

Associate Professor of Medicine

Division of Endocrinology, Department of Medicine

Federal University of São Paulo

Rua Pedro de Toledo 781, 13 andar

04039-032 São Paulo, SP

E-mail: kater@endocrino.epm.br 